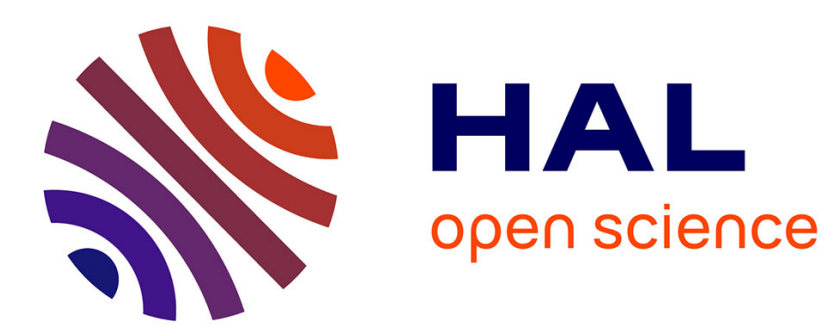

\title{
Spectral dependence of photocurrent for Cu2s-Cds solar cells
}

\author{
S. Martinuzzi, D. Sarti
}

\section{To cite this version:}

S. Martinuzzi, D. Sarti. Spectral dependence of photocurrent for Cu2s-Cds solar cells. Journal de Physique Lettres, 1978, 39 (21), pp.403-406. 10.1051/jphyslet:019780039021040300 . jpa-00231528

\section{HAL Id: jpa-00231528 https://hal.science/jpa-00231528}

Submitted on 1 Jan 1978

HAL is a multi-disciplinary open access archive for the deposit and dissemination of scientific research documents, whether they are published or not. The documents may come from teaching and research institutions in France or abroad, or from public or private research centers.
L'archive ouverte pluridisciplinaire HAL, est destinée au dépôt et à la diffusion de documents scientifiques de niveau recherche, publiés ou non, émanant des établissements d'enseignement et de recherche français ou étrangers, des laboratoires publics ou privés. 


\title{
SPECTRAL DEPENDENCE OF PHOTOCURRENT FOR $\mathrm{Cu}_{2} \mathrm{~S}-\mathrm{CdS}$ SOLAR CELLS
}

\author{
S. MARTINUZZI and D. SARTI \\ Laboratoire de Photoélectricité, Faculté des Sciences et Techniques de Marseille, \\ 13397 Marseille Cedex 4, France
}

(Reçu le 7 juillet 1978, révisé le 11 septembre 1978, accepté le 13 septembre 1978)

\begin{abstract}
Résumé. - On montre que la variation spectrale du photocourant de photopiles au $\mathrm{Cu}_{2} \mathrm{~S}-\mathrm{CdS}$ dépend de l'intensité de l'éclairement reçu par la photopile et de son état de polarisation électrique en influençant la contribution du CdS. Cette contribution, pour des longueurs d'onde voisines de $0,51 \mu \mathrm{m}$ peut surpasser celle du $\mathrm{Cu}_{2} \mathrm{~S}$ grâce à la multiplication des phototrous créés dans la région de charge d'espace du CdS et puissamment injectés dans le $\mathrm{Cu}_{2} \mathrm{~S}$.
\end{abstract}

Abstract. - It is shown that the spectral response of $\mathrm{Cu}_{2} \mathrm{~S}-\mathrm{CdS}$ photocells depends on the illumination level and electrical bias, which influence the $\mathrm{CdS}$ contribution. This contribution, for wavelengths about $0.51 \mu \mathrm{m}$ may exceed that of the $\mathrm{Cu}_{2} \mathrm{~S}$, by means of a multiplication of the photoholes generated in the $\mathrm{CdS}$ space charge layer and strongly injected into the $\mathrm{Cu}_{2} \mathrm{~S}$ part of the heterojunction.

1. Introduction. - The $\mathrm{Cu}_{2} \mathrm{~S}-\mathrm{CdS}$ solar cells, illuminated through the $\mathrm{Cu}_{2} \mathrm{~S}$, must present a spectral response resulting from the photogenerated electrons in the $\mathrm{p}$ type $\mathrm{Cu}_{2} \mathrm{~S}$ and from the photogenerated holes in the $\mathrm{n}$ type $\mathrm{CdS}$, as it is shown by figure $1 a$.

The energy gaps for $\mathrm{Cu}_{2} \mathrm{~S}$ and $\mathrm{CdS}$ are respectively 1.2 and $2.4 \mathrm{eV}$, so the spectral response of the short circuit current has to peak for wavelengths about 0.51 and $0.7 \mu \mathrm{m}[1,3]$ (Fig. 1b).

However, the $\mathrm{Cu}_{2} \mathrm{~S}$ optical absorption coefficient in the visible part of the solar spectrum is very strong $\left(\alpha>10^{4} \mathrm{~cm}^{-1}\right)$ and the corresponding radiations are practically absorbed in the $0.3 \mu \mathrm{m}$ thick $\mathrm{Cu}_{2} \mathrm{~S}$ layer. As the hole diffusion lengths are small in the CdS layers [4], only the photoholes generated in the CdS space charge region can contribute to the photocurrent. Consequently, Palz et al. [5] have concluded that the photocurrent results from the injection of photoelectrons from the $\mathrm{Cu}_{2} \mathrm{~S}$ into the $\mathrm{CdS}$. However, Gaswell et al. [6] have shown that the CdS contribution cannot be neglected and depends upon the cell preparation conditions. Recently, Rothwarf [7] has indicated that the spectral photosensitivity is related to the ionization of deep levels in the CdS space charge region.

The aim of this letter is to show that the spectral response of $\mathrm{Cu}_{2} \mathrm{~S}-\mathrm{CdS}$ cells depends essentially on the light illumination and electrical bias.

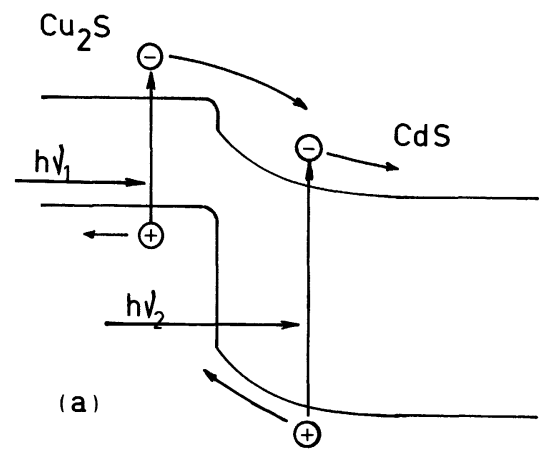

(b)

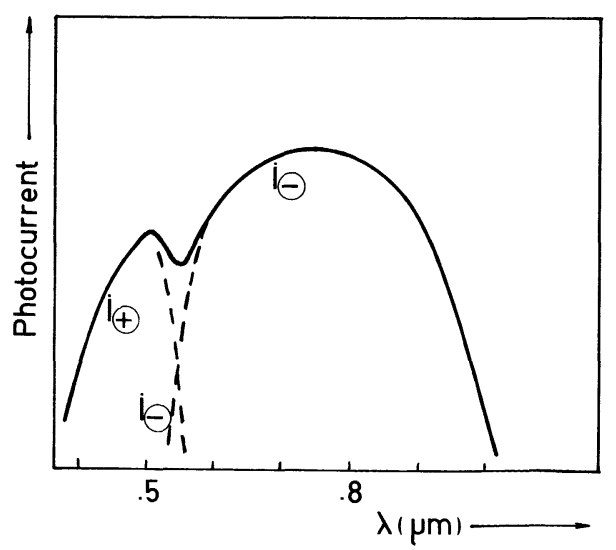

FIG. 1. - a) Schematic photovoltaic mechanism in a $\mathrm{p}-\mathrm{n}$ heterojunction of $\mathrm{Cu}_{2} \mathrm{~S}-\mathrm{CdS}$. b) Schematic spectral response of the above heterojunction. 
2. Experimental. - The photocells were prepared by S.A.T. (Paris) [5]. A $40 \mu \mathrm{m}$ thick CdS layer was evaporated onto a zinc covered kapton substrate. After etching in a normal $\mathrm{HCl}$ solution for $10 \mathrm{~s}$, the $\mathrm{CdS}$ layer was dipped in a saturated $\mathrm{CuCl}$ solution at $90^{\circ} \mathrm{C}$ and $\mathrm{pH} 4$ for $6 \mathrm{~s}$. This dipping produces a $0.3 \mu \mathrm{m}$ thick $\mathrm{Cu}_{2} \mathrm{~S}$ layer. The photocell preparation was achieved by the soldering of a gold plated copper grid and mylar encapsulation.

Three cells were cut to obtain six samples of $0.5 \mathrm{~cm}^{2}$.

The samples are introduced into a pumped thermostat vessel where they can be illuminated and electrically biased. A grating monochromator $\left(5 \mu \mathrm{W} . \mathrm{cm}^{-2}\right)$ and interference filters $\left(1 \mathrm{~mW} . \mathrm{cm}^{-2}\right)$ are used for the cell illumination. The monochromatic light levels may be adjusted with neutral filters and measured with standard U.D.T. photodetectors.

3. Results. - The spectral response of the shortcircuit photocurrent for different light levels $E_{\hat{\lambda}}$, are plotted in figure 2 . The relative contribution of the peak at $\lambda \simeq 0.51 \mu \mathrm{m}$ decreases as the power increases.

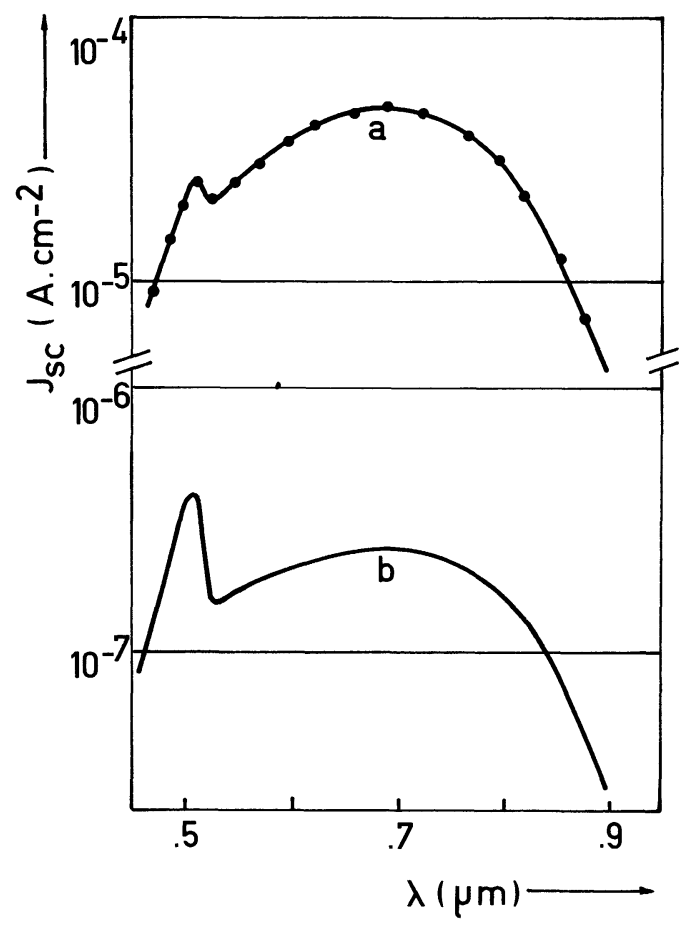

FIG. 2. - Modification of the spectral variation of the short circuit photocurrent for two illumination levels :a) $1 \mathrm{~mW} . \mathrm{cm}^{-2}$; b) $5 \mu \mathrm{W} \cdot \mathrm{cm}^{-2}$.

In contrast, a reverse bias $U_{\mathrm{r}}$ enhances the photosensitivity for $\lambda \simeq 0.51 \mu \mathrm{m}$ as it is shown by the figure 3 (the cells operate as photodiodes with an external load of $20 \Omega$ ).

The photocurrent for $\lambda \simeq 0.51 \mu \mathrm{m}$ increases sublinearly with $E_{\lambda}$, when the devices are short circuited or reverse biased, as seen in figure 4, while at $\lambda \simeq 0.73 \mu \mathrm{m}$, the photocurrent increases linearly with $E_{\lambda}$.

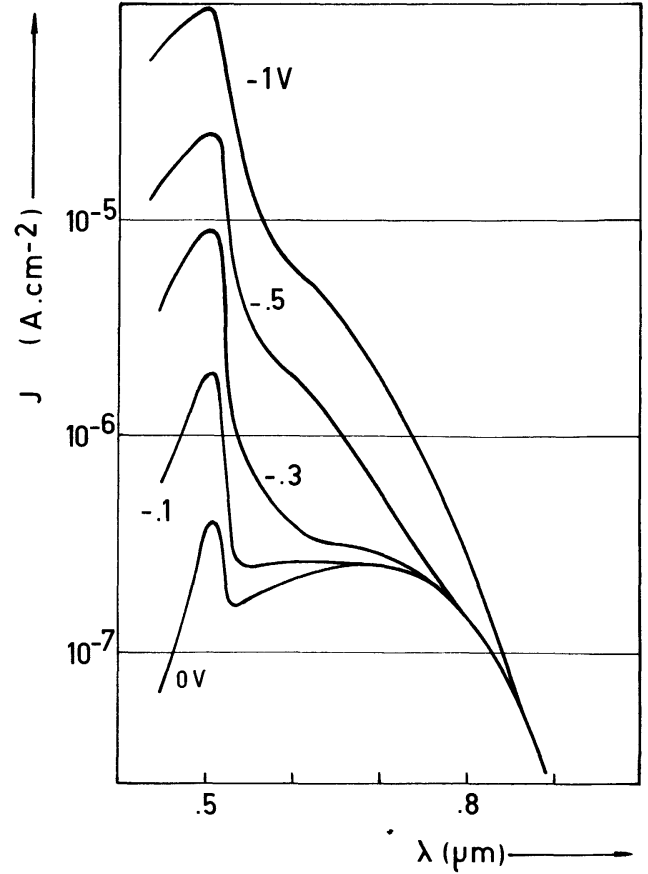

Fig. 3. - Spectral variation of the photocurrent at $5 \mu \mathrm{W} . \mathrm{cm}^{-2}$ illumination level for different reverse biases (external load $20 \Omega$ ).

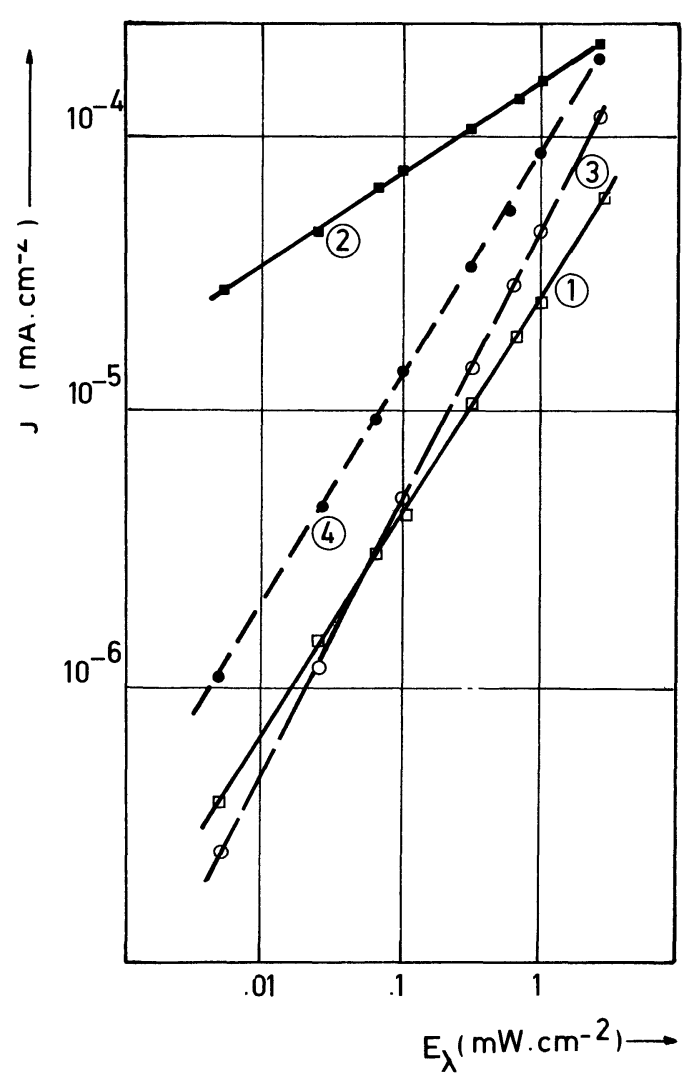

FIG. 4. - Photocurrent versus illumination level : (1) $\lambda \simeq 0.51 \mu \mathrm{m}$, zero bias ; (2) $\lambda=0.51 \mu \mathrm{m}, U_{\mathrm{r}}=-1 \mathrm{~V}$; (3) $\lambda=0.7 \mu \mathrm{m}$, zero bias ; (4) $\lambda=0.7 \mu \mathrm{m}, U_{\mathrm{r}}=-1 \mathrm{~V}$.

The current voltage curves of figure 5 give a further distinction : the characteristics are conventional for $\lambda \simeq 0.73 \mu \mathrm{m}$ while for $\lambda \simeq 0.51 \mu \mathrm{m}$, a soft break- 


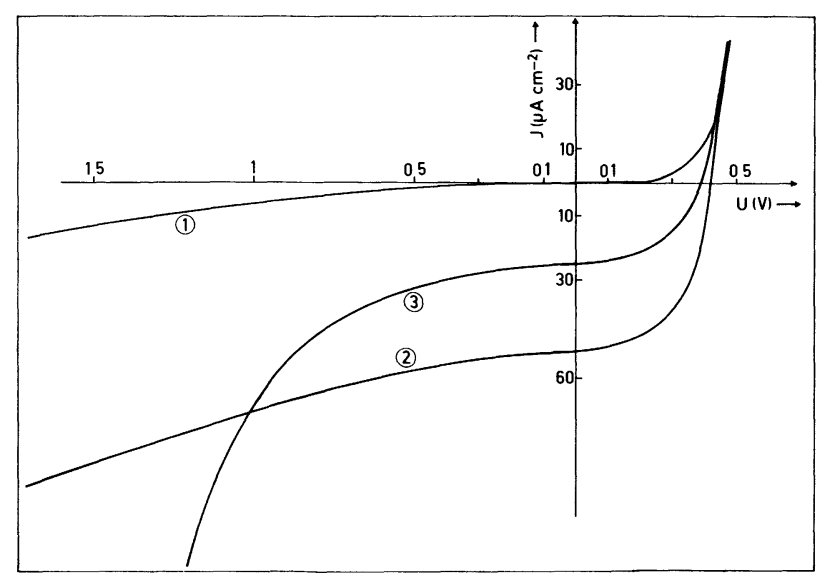

FIG. 5. - Current voltage characteristics : (1) : in dark ; (2) : $\lambda=0.73 \mu \mathrm{m}$ and $E_{\lambda}=1 \mathrm{~mW} . \mathrm{cm}^{-2} ;$ (3) $: \lambda=0.51 \mu \mathrm{m}$ and $E_{\lambda}=1 \mathrm{~mW} \cdot \mathrm{cm}^{-2}$.

down appears at a few tenths of a volt and the corresponding photocurrent $J_{\mathrm{p}}$ increases with $\left|U_{\mathrm{r}}\right|$ as $J_{\mathrm{p}} \sim\left|U_{\mathrm{r}}\right|^{n}$ with $n \simeq 4$ for $\left|U_{\mathrm{r}}\right|>0.5 \mathrm{~V}$.

The short circuited cells follow a $0.2 \mathrm{~ms}$ light pulse whereas in reverse bias a decay tail in the $10 \mathrm{~ms}$ range occurs.

The influence of a forward bias $U_{\mathrm{f}}$ on the spectral response is shown in the figure 6 . When $U_{\mathrm{f}}$ increases the peak at $0.51 \mu \mathrm{m}$ tends to disappear.

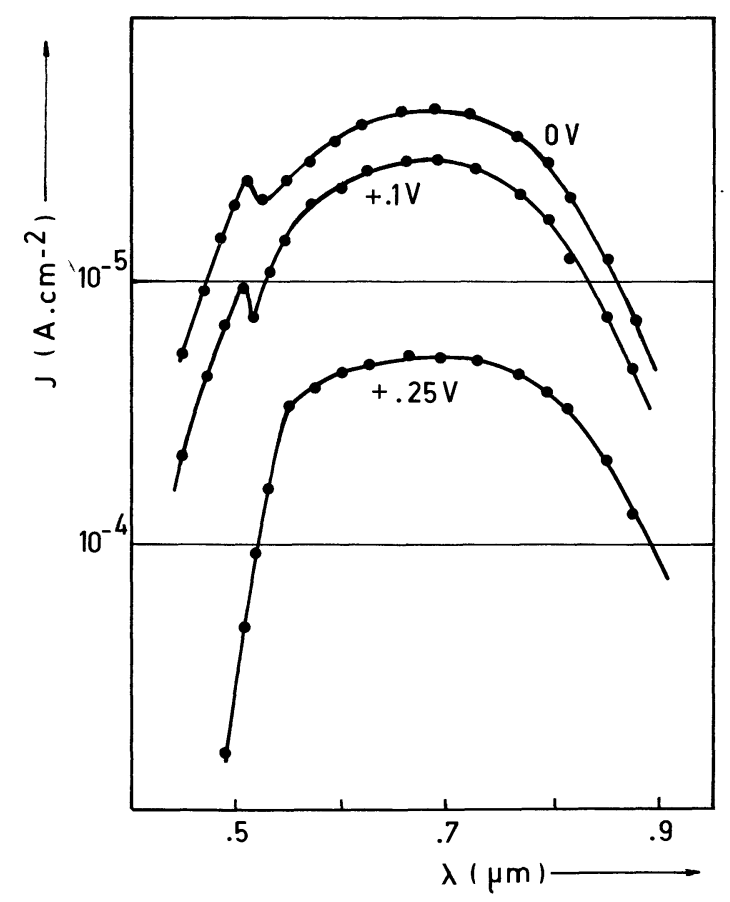

FIG. 6. - Spectral variation of the photocurrent at $E_{\lambda} \simeq 1 \mathrm{~mW} . \mathrm{cm}^{-2}$ for $U_{\mathrm{f}}=0,+0.1,+0.25 \mathrm{~V}$.
4. Discussion. - The preceding results indicate that the photosensitivity amplitude for $\lambda \simeq 0.51 \mu \mathrm{m}$ is dependent on the illumination level and the heterojunction electrical bias.

For $\lambda \simeq 0.51 \mu \mathrm{m}$, the observed photocurrents are essentially generated in the CdS space charge region, in spite of the strong optical absorption of the $0.3 \mu \mathrm{m} \mathrm{Cu}_{2} \mathrm{~S}$ layer (about $80 \%$ of the incident photons are absorbed). Indeed, it is well known that the CdS photoconduction peaks at $\lambda \simeq 0.51 \mu \mathrm{m}$, and that the band profile of the $\mathrm{Cu}_{2} \mathrm{~S}-\mathrm{CdS}$ heterojunction is similar to that of figure $1 a$ with practically, a space charge region entirely in the $\mathrm{CdS}$ because of the strong $\mathrm{Cu}_{2} \mathrm{~S}$ degeneracy [7-12]. So, only the CdS contribution to the photocurrent must be influenced by an electrical bias.

Assuming that, for $\lambda \simeq 0.51 \mu \mathrm{m}$ only $20 \%$ of the incident photons may reach the $\mathrm{CdS}$, a quantum efficiency and a collecting factor of about unity are necessary in order to obtain a photocurrent of $400 \mathrm{nA} \cdot \mathrm{cm}^{-2}$ for $E_{\lambda}=5 \mu \mathrm{W} . \mathrm{cm}^{-2}$, as in figure 2 . In this case, the strong increase of the photocurrent with $\left|U_{\mathrm{r}}\right|$ cannot result from a collecting factor increase.

Several interpretations may be cited in order to explain these results (such as combinations of photovoltaic and photoconductive effects), but actually we believe that the holes photogenerated in the CdS are strongly injected in the $\mathrm{Cu}_{2} \mathrm{~S}$ by the junction field, producing ionization and multiplication of carriers (this agrees particularly with the observed $J_{\mathrm{p}} \sim\left|U_{\mathrm{r}}\right|^{4}$ variation). So the cells operate like avalanching photodiodes for $\lambda \simeq 0.51 \mu \mathrm{m}$ for reverse bias, and also for zero bias.

This behaviour was also observed by Jordan [13] with $\mathrm{Cu}_{2} \mathrm{~S}-\mathrm{CdS}$ cells made by dipping chemically sprayed $\mathrm{CdS}$ layers into a $\mathrm{CuCl}$ solution.

The necessary fields for such a multiplication may result from the field and electronic density distribution in the space charge layer conceived by Boer [11], who makes the point that an illuminated junction is effectively reverse biased up to a solar illumination of about $50 \mathrm{~mW} \cdot \mathrm{cm}^{-2}$. Consequently, the multiplication of photoholes decreases when the junction is forward biased or when the illumination increases, so the photocurrent at $\lambda \simeq 0.51 \mu \mathrm{m}$ decreases.

5. Conclusions. - The spectral dependence of the $\mathrm{Cu}_{2} \mathrm{~S}-\mathrm{CdS}$ solar cell photocurrent results essentially from the contribution of the photoelectrons generated in the $\mathrm{Cu}_{2} \mathrm{~S}$. However, the $\mathrm{CdS}$ contribution (for $\lambda \simeq 0.51 \mu \mathrm{m}$ ) is amplified (probably by photohole multiplication) and exceeds that of $\mathrm{Cu}_{2} \mathrm{~S}$ at $\lambda \simeq 0.51 \mu \mathrm{m}$, provided the illumination intensity is low or the cell is reverse biased. 


\section{References}

[1] Marshall, R. and Mitra, S. S., J. Appl. Phys. 36 (1965) 3852.

[2] Ramoin, M., Sorbier, J. P., Bretzner, J.' F. and MartiNuzzı, S., C.R. Hebd. Séan. Acad. Sci., Paris 268 (1969) 1097.

[3] Mulder, B. J., Phys. Status Solidi (a) 2 (1970) K9.

[4] Partain, L. D., Oakes, J. J. and Greenfield, J. G., 10th IEEE Photovoltaic Specialists Conf. (1975), p. 45.

[5] Palz, W., Besson, J., Nguyen, T. and Vedel, J., Proc. 9th IEEE Photovoltaïc Specialists Conf. (1972), p. 62.

[6] Gaswell, B. G., Russel, G. J. and Woods, J., J. Phys. D. Appl. Phys. 8 (1975) 1889.

[7] Rothwarf, A., Proc. Int. Conf. « Solar Electricity » C.N.R.S.C.N.E.S. Toulouse (1976), p. 273.
[8] Brandhorst, W. H., Proc. 7th IEEE Photovoltaic Specialists Conf. (1968), p. 33

[9] Fahrenbruch, A. L. and Bube, R. H., J. Appl. Phys. 45 (1974) 1264.

[10] Hewig, G. H., Pfisterer, F. and Bloss, W. H., Proc. of Int. Conf. Photovoltaic Power Generation Hamburg (1974), p. 255.

[11] Boer, K. W., Phys. Rev. B 13 (1976) 5273.

[12] Martinuzzi, S., Mallem, O. and Cabot, T., Phys. Status Solidi (a) 36 (1976) 227.

[13] Jordan, J. F., Proc. of Int. Conf. « Solar Electricity » C.N.R.S.C.N.E.S. Toulouse (1976), p. 57. 